\title{
LOW DOSES OF FENOFIBRATE AND BEZAFIBRATE STIMULATE RENAL 2-OXOGLUTARATE DEHYDROGENASE (2-OGDH) IN PROTEIN-RESTRICTED RATS
}

\author{
MALGORZATA E. KNAPIK-CZAJKA*, JAGODA M. DRAG and ANNA GAWEDZKA
}

Department of Biochemical Analytics, Faculty of Pharmacy, Jagiellonian University Medical College, 9 Medyczna St., 30-688 Kraków, Poland

\begin{abstract}
OGDH) is the key regulatory enzyme of cell metabolism. It has been previously demonstrated that in rats subjected to protein restriction low, clinically relevant doses of fibrates up-regulate liver 2-OGDH and promote 2-oxoglutarate catabolism. The aim of the present study was to evaluate the effect of low doses of fenofibrate and bezafibrate on renal 2-OGDH complex in rats fed low-protein chow. Fibrates were administered for 14 days to Wistar male rats at one daily dose of $5,10 \mathrm{or} 20 \mathrm{mg} / \mathrm{kg}$ b.wt./day. The 2-OGDH activity was assayed spectrophotometrically. The mRNA levels for 2-OGDH catalytic subunits (E1 and E2) and PPAR $\alpha$ were quantified by means of semi-quantitative reverse-transcription-PCR. 2-OGDH activity increased in response to administration of fenofibrate and bezafibrate (by 11, 24, 32\% and 9, $12,21 \%$, respectively). The difference was statistically significant for the doses of 10 and $20 \mathrm{mg} / \mathrm{kg} \mathrm{b}$.wt of fenofibrate $(\mathrm{p}<0.001)$ and the highest dose of bezafibrate $(\mathrm{p}<0.05)$. The stimulation of 2-OGDH was not accompanied by changes in mRNA levels for E1 and E2. In addition, the mRNA level for PPAR $\alpha$ did not change. It is conceivable that fibrate-induced stimulation of 2-OGDH activity can affect renal metabolism and contribute to changes in kidney functions.
\end{abstract}

Keywords: 2-oxoglutarate dehydrogenase, fenofibrate, bezafibrate, kidney

Fibrates, including fenofibrate and bezafibrate, are a group of hypolipidemic drugs that are commonly used to treat dyslipidemia which is associated with type 2 diabetes mellitus and metabolic syndrome (1). At a molecular level, fibrates bind to peroxisome proliferator-activated receptors (PPAR) and regulate the transcription of genes for different proteins, particularly those involved in lipid metabolism (2). Fenofibrate binds primarily to PPAR $\alpha$, while bezafibrate is an agonist for all three PPAR isoforms (3). In addition, fibrates exert numerous biological activities which are PPAR-independent $(4,5)$.

It has been found that fibrates regulate enzymes belonging to the mitochondrial family of 2oxoacid dehydrogenases $(6,7)$. 2-oxoglutarate dehydrogenase (2-OGDH - EC 1.2.4.2; also known as the $\alpha$-ketoglutarate dehydrogenase, $\alpha-\mathrm{KGDH})$, branched-chain $\alpha$-ketoacid dehydrogenase $(\mathrm{BCKDH})$ and pyruvate dehydrogenase (PDH) share some common structural and functional fea- tures and they all catalyze the decarboxylation of their respective 2-oxoacids (8).

2-OGDH, the key control enzyme of a tricarboxylic acid cycle, catalyzes the conversion of 2oxoglutarate (2-OG), coenzyme $\mathrm{A}$ and $\mathrm{NAD}^{+}$to succinyl-CoA, NADH and $\mathrm{CO}_{2}$. The complex consists of multiple copies of three catalytic subunits: 2oxoglutarate dehydrogenase (E1), dihydrolipoamide succinyltransferase (E2) and dihydrolipoamide dehydrogenase (E3). The E1 and E2 subunits are unique for the 2-OGDH, while E3 subunit is loosely bounded to this complex and after dissociation it can associate with other complexes belonging to the family of 2-oxoacid dehydrogenases.

It has been shown that fibrates increase liver 2OGDH and BCKDH complex activities and stimulate 2-OG and branched-chain amino acid catabolism, respectively $(6,9)$. This effect is especially marked in rats fed a low-protein diet $(7,10)$. Stimulation of 2-OGDH and BCKDH in proteinrestricted rats has been demonstrated not only for

\footnotetext{
* Corresponding author: e-mail: malgorzata.knapik-czajka@uj.edu.pl
} 
high, experimental but also for low, more clinically relevant doses of fibrates. In addition, fibrates may also change mRNA levels for catalytic subunits of the complexes, though this effect is dependent on the dose used $(9,10,11,12)$.

Liver parenchymal and renal tubular cells share many of the same enzymes and metabolic pathways. It has also been shown that fibrates can affect kidney functions $(13,14,15)$. Therefore we wanted to examine the influence of low, clinically relevant doses (16) of fibrates on renal 2-OGDH complex. The present study was undertaken to investigate the in vivo effect of fenofibrate and bezafibrate (at doses of 5,10 and $20 \mathrm{mg}$ $\mathrm{kg} / \mathrm{b}$.wt/day) on 2-OGDH complex in the kidney of rats fed a low-protein diet ( $8 \%$ protein). In addition, mRNA levels for 2-OGDH catalytic subunits (E1 and E2) and PPAR $\alpha$ were measured.

\section{EXPERIMENTAL}

\section{Reagents}

All chemicals used in experiments were purchased from Sigma-Aldrich Chemical Company (Germany). A low-protein diet (8\% protein) was bought from MP Biomedicals (USA). NG dART RT kit and Perpetual Opti Taq DNA polymerase were purchased from Eurx (Poland). Primers were synthesized by Blirt DNA Gdansk (Poland).

\section{Animals and experimental treatment}

Animal experiments were conducted in accordance with the guidelines for animal experiments and all procedures were approved by the First Local Ethical Committee on Animal Testing at the Jagiellonian University, Krakow, Poland. Male Wistar rats (from the inbred strain) were purchased from the breeding facility of the Jagiellonian University Faculty of Pharmacy. They were housed four per cage and maintained under standardized conditions of artificial 12-hours light/dark cycle in constant room temperature $\left(21-23^{\circ} \mathrm{C}\right)$. All rats were fed low-protein diet ( $8 \%$ protein content) ad libitum and were allowed free access to water. Rats $(n=28)$ were randomized into 7 treatment groups $(n=4$ each). Group 1 (control group - $0 \mathrm{mg} / \mathrm{kg}$ b.wt fibrate): rats administered with $0.3 \%$ dimethylcellulose solution (agent's vehicle). Groups 2, 3 and 4: rats treated with fenofibrate (propan-2-yl 2-[4-(4chlorobenzoyl)phenoxy]-2-methylpropanoate) at the dose of 5; 10 and $20 \mathrm{mg} / \mathrm{kg}$ b.wt, respectively. Groups 5, 6 and 7: rats treated with bezafibrate (2(4-\{2-[(4-chlorophenyl)formamido]ethyl $\}$ phenoxy)-2-methylpropanoic acid) at the dose of $5 ; 10$ and $20 \mathrm{mg} / \mathrm{kg}$ b.wt, respectively. The doses were chosen based on our earlier study on the effect of fibrates on liver 2-OGDH complex (10). Fibrates were administered by intragastric gavage for 14 days (once daily). On day 15, rats were sacrificed, kidneys were excised and immediately freezeclamped with aluminum tongs precooled in liquid nitrogen and then stored at $-80^{\circ} \mathrm{C}$ until analysis.

\section{Determination of 2-OGDH activity}

Tissue extracts for the assay of renal 2-OGDH activity were prepared as described previously (17). Briefly, a portion of frozen renal tissue was powdered in liquid nitrogen, weighed and homogenized in an extraction buffer. 2-OGDH was then concentrated from the whole tissue extract by precipitation with $9 \%$ polyethylene glycol. 2-OGDH activity (in the presence of thiamine diphosphate in the assay cocktail) was determined spectrophotometrically at $30^{\circ} \mathrm{C}$ by measuring the rate of $\mathrm{NADH}$ generation from $\mathrm{NAD}^{+}$(at $340 \mathrm{~nm}$ ) using the saturating concentration of 2-OG, a substrate for 2-OGDH complex (Cary 100 spectrophotometer-Varian). In contrast to Blair et al. (17), the assay buffer was made without dihydrolipoamide dehydrogenase (18). One unit of 2-OGDH complex activity is defined as the

Table 1. Sequences, concentrations and annealing temperatures of primers used in PCR.

\begin{tabular}{|c|c|c|c|}
\hline $\begin{array}{l}\text { Gene amplified } \\
\text { (product bp) }\end{array}$ & $\begin{array}{c}\text { Primer } \\
\text { Sequence }\end{array}$ & $\begin{array}{l}\text { Primer concentration } \\
(\mathrm{pmol} / \mathrm{L})\end{array}$ & $\begin{array}{c}\text { Annealing } \\
\text { temperature }\left({ }^{\circ} \mathrm{C}\right)\end{array}$ \\
\hline $\begin{array}{c}\mathrm{E} 1 \\
(347)\end{array}$ & $\begin{array}{l}\text { 5'- GGA GAC AGG TAT TTG TGG AAG GC -3' } \\
\text { 5'- CCA GGG AGC TTC GAC TCA GG -3' }\end{array}$ & $\begin{array}{l}4 \\
4\end{array}$ & 65 \\
\hline $\begin{array}{c}\mathrm{E} 2 \\
(339)\end{array}$ & $\begin{array}{l}\text { 5'- AGA TGT CAG GTG GGA GAA AG -3' } \\
\text { 5'- GGT TTG CTA GAA GGA GGT TG -3' }\end{array}$ & $\begin{array}{l}4 \\
4\end{array}$ & 60 \\
\hline $\begin{array}{l}\text { PPAR } \alpha \\
(510)\end{array}$ & $\begin{array}{l}\text { 5'- TCA GAG GTC CCT GAA CAG TG -3' } \\
\text { 5'- AAG CCA TCT TCA CGA TGC TG -3' }\end{array}$ & $\begin{array}{l}2 \\
2\end{array}$ & 60 \\
\hline $\begin{array}{l}\beta \text {-actin } \\
(228)\end{array}$ & $\begin{array}{l}\text { 5'- AGC CAT GTA CGT AGC CAT CC -3' } \\
\text { 5'- CTC TCA GCT GTG GTG GTG AA -3' }\end{array}$ & $\begin{array}{l}4 \\
4\end{array}$ & 55 \\
\hline
\end{tabular}




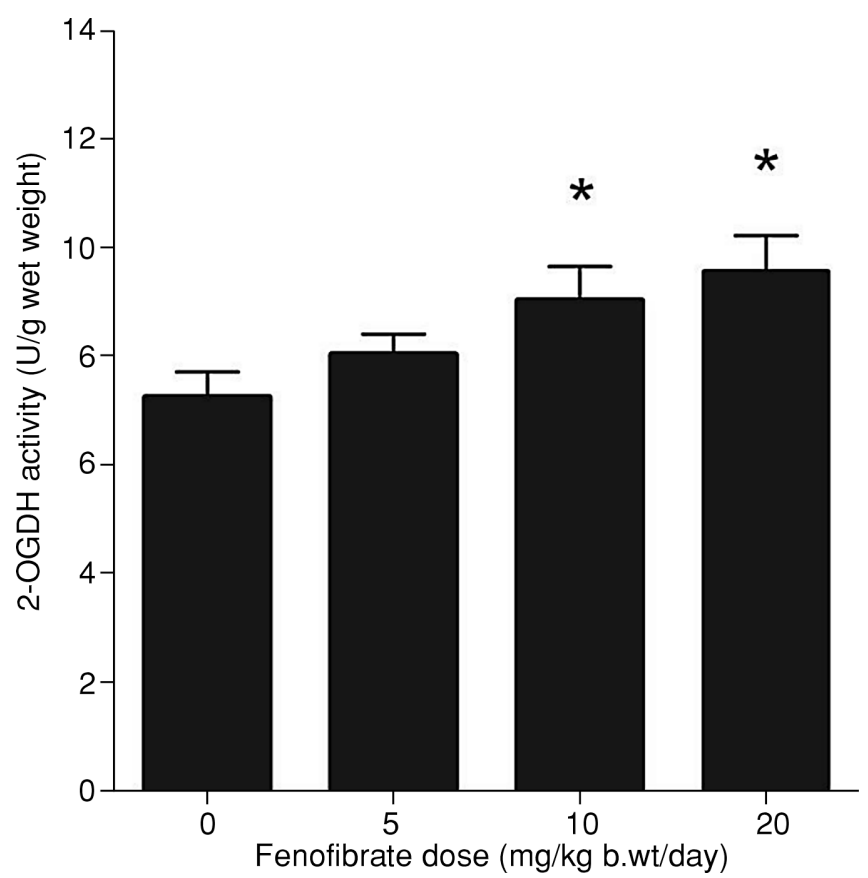

Figure 1. Effect of increasing doses of fenofibrate on renal 2-OGDH activity. Rats were fed a low-protein diet and administered with 5, 10 or $20 \mathrm{mg} / \mathrm{kg} \mathrm{b}$.wt/day of fenofibrate or given only the vehicle (control group $-0 \mathrm{~g} / \mathrm{kg} \mathrm{b}$.wt/day fenofibrate). 2-OGDH activity was determined spectrophotometrically at $30^{\circ} \mathrm{C}$ by measuring the rate of $\mathrm{NADH}$ generation at $340 \mathrm{~nm}$. Data are presented as mean $\pm \mathrm{SD}(\mathrm{n}=4)$. ${ }^{*} \mathrm{p}$ $<0.001$ compared to the control group.

amount of enzyme that catalyzed the formation of 1 $\mu \mathrm{mol}$ of $\mathrm{NADH} / \mathrm{min}$.

\section{Determination of mRNA levels}

Relative levels of specific mRNA for 2-OGDH catalytic subunits (E1 and E2) and PPAR $\alpha$ were assessed by semi-quantitative reverse transcriptionpolymerase chain reaction (RT-PCR). Total RNA was isolated with TRI reagent (Sigma-Aldrich, Germany) and cDNA was subsequently synthesized using $1 \mu \mathrm{g}$ total RNA, reverse-transcriptase and oligo dT primers (NG dART RT kit, Eurx, Poland). cDNA was amplified with Perpetual Opti Taq DNA polymerase (Eurx, Poland) following the manufacturer's instructions. PCR reactions were performed with ratspecific primers (Table 1) that were designed for the genes of interest using Primer-BLAST software (NCBI). Each gene was amplified together with a housekeeping gene $\beta$-actin (internal control). After an initial denaturation at $95^{\circ} \mathrm{C}, \mathrm{PCR}$ was carried out for 35 cycles. Each cycle consisted of denaturation at $95^{\circ} \mathrm{C}$ for 40 seconds, primer annealing for 30 seconds and primer extension at $72^{\circ} \mathrm{C}$ for 30 seconds. The PCR products were subjected to agarose gel electrophoresis (1.5\% agarose gel), stained with ethidium bromide and analyzed by densitometry using the Quantity One software (Bio-Rad). Obtained data were first normalized to $\beta$-actin (in the same sample) and then expressed relative to the control group (vehicle-treated rats). The relative level of particular mRNA in each fibrate treated group was presented using arbitrary units (\% of the control group).

\section{Statistical analysis}

Statistical calculations and graphs were done using GraphPad Prism version 5.0 (GraphPad Software, Inc., San Diego, CA, USA). Data were presented as mean \pm SD. Differences between groups were determined with one-way analysis of variance (ANOVA), followed, when appropriate, by Bonferroni post hoc test, with acceptable significance levels set at $\mathrm{p}<0.05$.

\section{RESULTS}

\section{Effect of fibrates on 2-OGDH activity}

Both fenofibrate and bezafibrate administered to protein-restricted rats stimulated renal 2-OGDH activity in a dose-dependent manner. In rats that received 5, 10 and $20 \mathrm{mg} / \mathrm{kg}$ b.wt fenofibrate 2OGDH activity increased by $11 \%, 24 \%$ and $32 \%$ in comparison to the control group, respectively. The difference was statistically significant for the doses of 10 and $20 \mathrm{mg} / \mathrm{kg} \mathrm{b.wt} \mathrm{(p<0.001)} \mathrm{(Fig.} \mathrm{1).}$ 
In bezafibrate-treated rats mean 2-OGDH activity was $9 \%, 12 \%$ and $21 \%$ higher than in the untreated animals. The difference was statistically significant for rats given the highest dose of bezafibrate $(\mathrm{p}<0.05)$ (Fig. 2).

Effect of fibrates on mRNA levels for E1 and E2 subunits of 2-OGDH complex

The effect of fenofibrate and bezafibrate on mRNA levels of E1 and E2 subunits is presented in Figure 3 and Figure 4. Mean E1 mRNA levels in rats given 5,10 and $20 \mathrm{mg} / \mathrm{kg}$ b.wt fenofibrate were lower than in the control group (95 $\pm 1 \%$; $95 \pm 4 \%$ and $95 \pm 3 \%$ vs $100 \pm 2 \%$, respectively) (Fig. 3a). Similarly, E2 mRNA levels decreased by $3 \%, 1 \%$ and $4 \%$, respectively as compared to vehicle-treated animals (Fig. 3b). The differences were not statistically significant $(\mathrm{p}>0.05)$.

In rats given 5,10 and $20 \mathrm{mg} / \mathrm{kg}$ b.wt bezafibrate E1 mRNA levels were 1\%,6\% and 6\% lower than in the control group (Fig. 4a). In rats treated with $5 \mathrm{mg} / \mathrm{kg}$ b.wt bezafibrate E2 mRNA level was lower, while with $20 \mathrm{mg} / \mathrm{kg}$ b.wt higher than in the control group ( $91 \pm 8 \%$ and $103 \pm 5 \%$ vs $100 \pm 2 \%$, respectively). Mean E2 mRNA level in rats given 10 $\mathrm{mg} / \mathrm{kg}$ b.wt bezafibrate was the same as in the vehi- cle-treated group $(100 \pm 6 \%$ vs $100 \pm 2 \%)$ (Fig. 4b) The differences were not statistically significant $(\mathrm{p}>$ 0.05).

\section{Effect of fibrates on mRNA levels for PPAR $\alpha$}

There was no significant difference in the mean renal mRNA abundance for PPAR $\alpha$ between fenofibrate treated groups and control rats $(94 \pm 3 \%$, $90 \pm 3 \%$ and $93 \pm 4 \%$ vs. $100 \pm 11$ for the control group) (Fig. 5a). Mean relative mRNA levels for PPAR $\alpha$ were $4 \%, 5 \%$ and $7 \%$ lower in bezafibrate treated groups than in the vehicle-treated animals ( $\mathrm{p}$ $>0.05$ ) (Fig. 5b).

\section{DISCUSSION AND CONCLUSION}

This study demonstrated that administration of low doses bezafibrate and fenofibrate to proteinmalnourished rats caused dose-dependent stimulation of renal 2-OGDH activity. Taking into account the results of the present and previous studies (10) it can be concluded that low doses of fenofibrate and bezafibrate increase 2-OGDH activity both in liver and kidney of rats fed a low-protein diet.

It is well documented that 2-OGDH activity is controlled mainly post-translationally by different

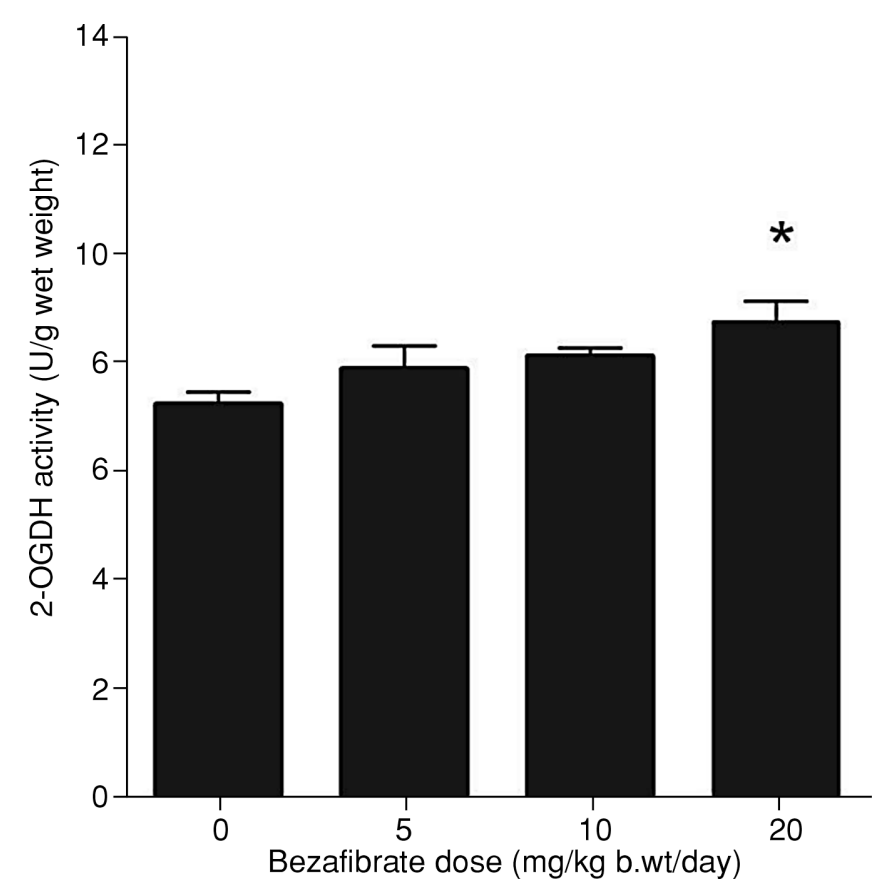

Figure 2. Effect of increasing doses of bezafibrate on renal 2-OGDH activity. Rats were fed a low-protein diet and administered with 5, 10 or $20 \mathrm{mg} / \mathrm{kg} \mathrm{b}$.wt/day of bezafibrate or given only the vehicle (control group $-0 \mathrm{~g} / \mathrm{kg} \mathrm{b}$.wt/day bezafibrate). 2-OGDH activity was determined spectrophotometrically at $30^{\circ} \mathrm{C}$ by measuring the rate of $\mathrm{NADH}$ generation at $340 \mathrm{~nm}$. Data are presented as mean $\pm \mathrm{SD}(\mathrm{n}=4)$. ${ }^{*} \mathrm{p}$ $<0.05$ compared to the control group. 


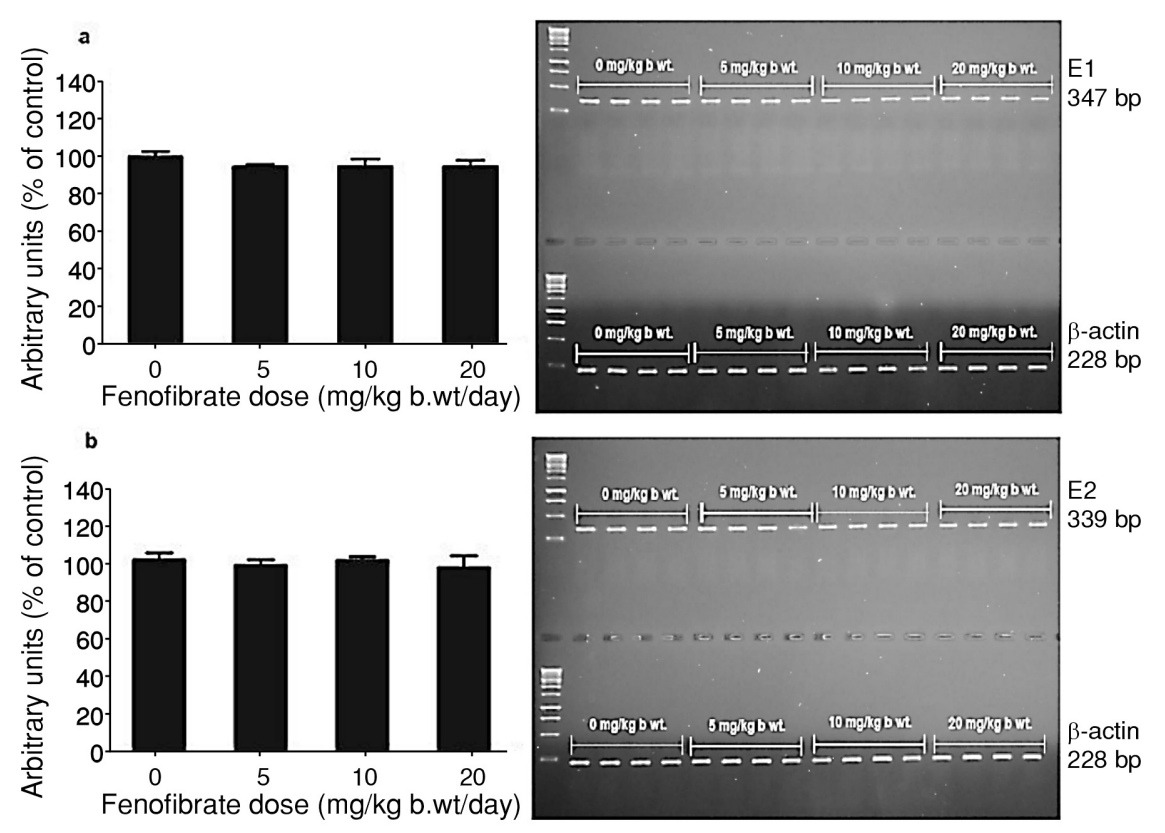

Figure 3. Effect of increasing doses of fenofibrate on renal 2-OGDH catalytic subunits E1 (a) and E2 (b) mRNA levels. Rats were fed a low-protein diet and administered with 5,10 or $20 \mathrm{mg} / \mathrm{kg} \mathrm{b}$.wt/day of fenofibrate or given only the vehicle (control group $-0 \mathrm{~g} / \mathrm{kg} \mathrm{b.wt} / \mathrm{day}$ fenofibrate). The relative levels of E1 and E2 mRNA were measured by means of semi-quantitative RT-PCR, quantitated by densitometry then normalized to $\beta$-actin mRNA (in the same sample) and expressed relative to the control rats (arbitrary units-\% of control). Right panel: representative agarose gel. Left panel: bar graph displaying the mean values \pm SD.

factors (19). The 2-OGDH complex undergoes allosteric inhibition by high succinyl-CoA/CoA, $\mathrm{NADH} / \mathrm{NAD}^{+}$and $\mathrm{ATP} / \mathrm{ADP}$ ratios $(19,20)$. In addition, calcium ions increase 2-OGDH activity $(21,22)$. In the present study, it was found that fenofibrate and bezafibrate had no effect on mRNA levels for E1 and E2 catalytic subunits. We can speculate that fibrates exert some effects on the factors regulating 2-OGDH activity. Jiao et al. (23) demonstrated that fenofibrate treatment increased cellular calcium levels. In addition, clofibrate, the parent compound of fibrates group, increases the concentration of free CoA and reduces succinylCoA level leading to the reduction of succinyl$\mathrm{CoA} / \mathrm{CoA}$ ratio (24). It seems likely that clofibrate analogs, fenofibrate, and bezafibrate, have a similar effect on succinyl-CoA/CoA ratio.

Stimulation of liver BCKDH complex by fibrates was associated with increased dephosphorylation of the complex $(12,25)$. Until recently it has been thought that in contrast to $\mathrm{BCKDH}$, the activity of 2-OGDH is not regulated by reversible phosphorylation. However, recent study demonstrated that phosphorylation of 2-OGDH mediated by c-jun $\mathrm{N}$-terminal protein kinase (JNK) resulted in the inactivation of the complex (26). It was also found that fenofibrate inhibited JNK activation (27).
Therefore, an increase in 2-OGDH activity upon fibrates treatment could be associated with decreased phosphorylation of the complex.

It also seems likely that fibrates increased 2OGDH activity by attenuating renal oxidative stress. 2-OGDH complex is uniquely sensitive to oxidative stress, capable of undergoing free radical-mediated inhibition $(28,29)$. Fibrates reduce $\mathrm{NAD}(\mathrm{P}) \mathrm{H}$ oxidase activity and increase the activities of free radical scavenging enzymes, including superoxide dismutase, catalase, and glutathione peroxidase (30, 31).

It was found that low doses of bezafibrate and fenofibrate did not change renal mRNA levels for PPAR $\alpha$. This result is in good agreement with our recent study on the effect of fibrates on liver PPAR $\alpha$ (10). In addition, it is consistent with results obtained by Nakajima et al. (32) who showed that administration of low, clinically relevant doses of fibrates resulted in a reduction of serum/liver TG but was not associated with changes in mRNA level for PPAR $\alpha$.

It is probable that an increase in $2-\mathrm{OGDH}$ activity induced by fibrates may lead to changes in renal metabolism. It has been demonstrated that stimulation of 2-OGDH triggers a significant decrease in 2-OG concentration (33). 2-OG is a mas- 


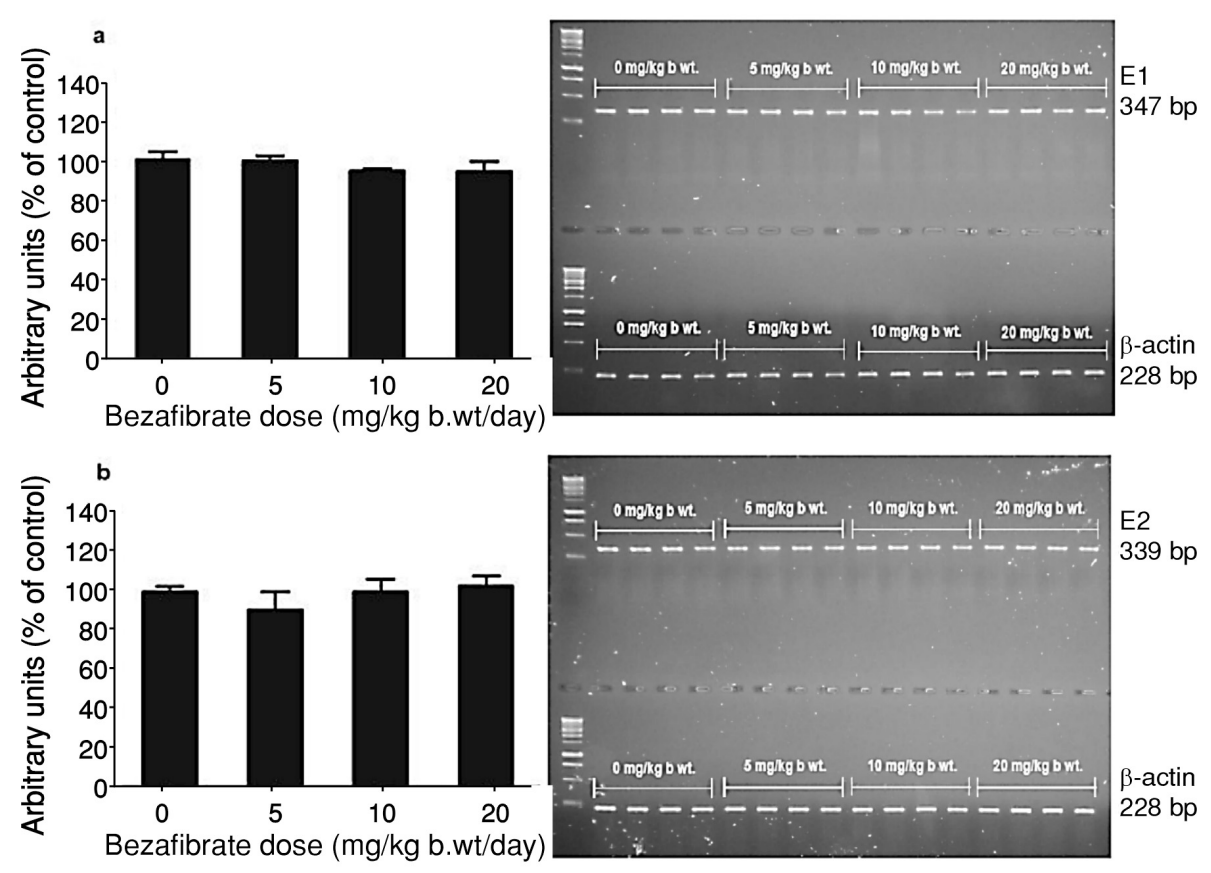

Figure 4. Effect of increasing doses of bezafibrate on renal 2-OGDH catalytic subunits E1 (a) and E2 (b) mRNA levels. Rats were fed a low-protein diet and administered with 5,10 or $20 \mathrm{mg} / \mathrm{kg} \mathrm{b}$.wt/day of bezafibrate or given only the vehicle (control group $-0 \mathrm{~g} / \mathrm{kg} \mathrm{b.wt} / \mathrm{day}$ bezafibrate). The relative levels of E1 and E2 mRNA were measured by means of semi-quantitative RT-PCR, quantitated by densitometry then normalized to $\beta$-actin mRNA (in the same sample) and expressed relative to the control rats (arbitrary units-\% of control). Right panel: representative agarose gel. Left panel: bar graph displaying the mean values \pm SD.

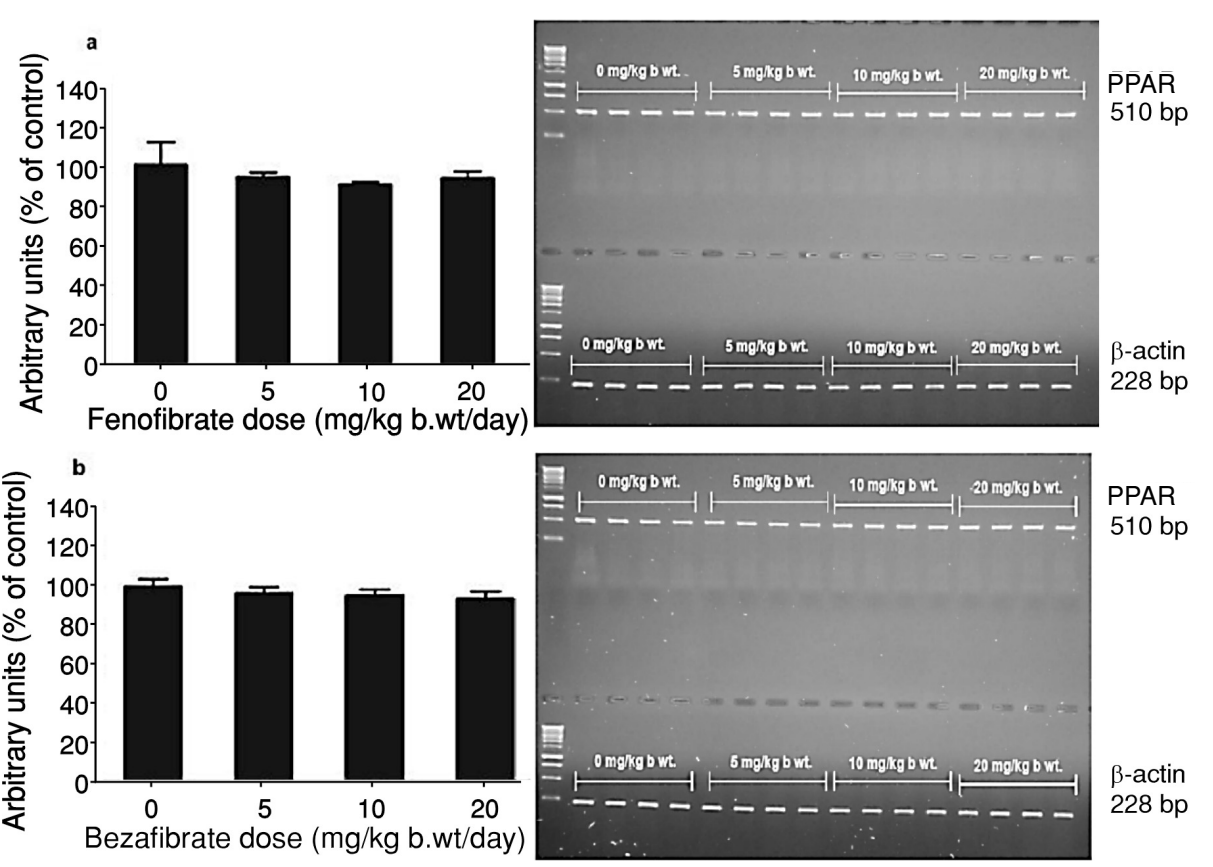

Figure 5. Effect of increasing doses of fenofibrate (a) and bezafibrate (b) on mRNA levels for PPAR $\alpha$. Rats were fed a low-protein diet and administered with 5,10 or $20 \mathrm{mg} / \mathrm{kg}$ b.wt/day of fibrate or given only the vehicle (control group $-0 \mathrm{~g} / \mathrm{kg} \mathrm{b} . \mathrm{wt} / \mathrm{day}$ fibrate). The relative levels mRNA levels for PPAR $\alpha$ were measured by means of semi-quantitative RT-PCR, quantitated by densitometry then normalized to $\beta$-actin mRNA (in the same sample) and expressed relative to the control rats (arbitrary units-\% of control). Right panel: representative agarose gel. Left panel: bar graph displaying the mean values \pm SD. 
ter regulator of multiple metabolic and cellular pathways in different tissues, including kidneys. Schoolwerth et al. (33) found that an increase in 2OGDH flux and reduced 2-OG level were associated with enhanced renal ammoniagenesis. In addition, a decline in 2-OG was connected with an acceleration of renal gluconeogenesis (34). Furthermore, 2-OG regulates renal $\mathrm{Cl}$-dependent $\mathrm{HCO}_{3}{ }^{-}$secretion and electroneutral transepithelial $\mathrm{NaCl}$ reabsorption (35). Therefore, it may be reasonable to assume that the stimulation of 2-OGDH by fibrates could modify crucial metabolic pathways in kidneys.

Since 2-OGDH catalyzes the conversion of 2OG to succinyl-CoA in the presence of the CoA thereby reducing $\mathrm{NAD}^{+}$to $\mathrm{NADH}$, the increase in 2OGDH activity would be expected to decrease $\mathrm{NAD}^{+}$ in mitochondria. $\mathrm{NAD}^{+}$serves as a key cofactor for numerous enzymes involved in energy metabolism and also has several other important cellular functions, including regulation of multiple cell signaling pathways $(36,37)$. It was demonstrated that the decline in renal level of $\mathrm{NAD}^{+}$was associated with a general reduction in mitochondrial function (38). In addition, $\mathrm{NAD}^{+}$depletion is emerging as a major contributor to the pathogenesis of renal diseases (39).

Some reports have indicated that fibrates can induce renal impairment $(13,15,40)$. Fibrate therapy is associated with elevation in serum creatinine and reduced estimated glomerular filtration rates $(14,41)$. The mechanism of this effect has not been fully elucidated. Ncube et al. (42) suggested that the decrease in estimated glomerular filtration rate upon fibrates treatment was a genuine effect on kidney functions rather than a change in creatinine metabolism. Kidney functions were not evaluated in the present study. However, taking into account obtained results one cannot exclude the possibility that in condition of protein restriction fibrates disturb renal metabolism leading to alternation in kidney functions.

In conclusion, obtained results indicate that low doses of fenofibrate and bezafibrate up-regulated renal 2-OGDH activity in rats fed a low-protein diet. Stimulation of 2-OGDH was not accompanied by changes in mRNA levels for catalytic subunits, E1 and E2 suggesting that fibrates exert some effects on factors regulating the complex activity. In addition, the effect of fibrates was not associated with changes in the mRNA level for PPAR $\alpha$. It is conceivable that fibrate-induced stimulation of 2OGDH activity can affect renal metabolism and contribute to changes in kidney functions. Further studies are required to elucidate the influence of fibrates on kidneys.

\section{Acknowledgments}

This study was supported by the State Committee for Scientific Research, Poland - grant number 3 P05F 032-25 and by Jagiellonian University Medical College, Krakow, Poland - project number K/ZDS/006252. The authors would like to thank Katarzyna Wadowska and Anna Cichon for their excellent technical support.

\section{Conflict of interest}

All authors declare that they have no conflict of interests.

\section{REFERENCES}

1. Chapman M.J.: Atherosclerosis 171, 1 (2003).

2. Staels B., Dallongeville J., Auwerx J., Schoonjans K., Leitersdorf E., et al.: Circulation 98, 2088 (1998).

3. Tenenbaum A., Motro M., Fisman E.Z.: Cardiovasc. Diabetol. 4, 14 (2005).

4. Nakajima T., Tanaka N., Sugiyama E., Kamijo Y., Hara A., et al.: Biochem. Pharmacol. 76, 108 (2008).

5. Scatena R., Bottoni P., Vincenzoni F., Messana I., Martorana G.E., et al: Chem. Res. Toxicol. 16, 1440 (2003).

6. Prager C., Schön H.J., Nikfardjam M., Schmid D., Untersalmberger M., et al.: J. Lipid Res. 34, 359 (1993).

7. Kobayashi R., Murakami T., Obayashi M., Nakai N., Jaskiewicz J., et al.: Arch. Biochem. Biophys. 407, 231 (2002).

8. Yeaman S.J.: Biochem. J. 257, 625 (1989).

9. Ono K., Shioya H., Hakozaki M., Honda K., Mori T., et al.: Biochem. Biophys. Res. Commun. 172, 243 (1990).

10. Knapik-Czajka M.E.: Bangladesh J. Pharmacol. 10, 505 (2015).

11. Knapik-Czajka M., Tyszka-Czochara M., Jaśkiewicz J.: Acta Toxicol. 11, 59 (2003).

12. Knapik-Czajka M.: Toxicology 306, 101 (2013).

13. Attridge R.L., Frei C.R., Ryan L., Koeller J., Linn W.D.: Am. J. Health Syst. Pharm. 70, 1219 (2013).

14. Kim S., Ko K., Park S., Lee D.R., Lee J.: Korean J. Fam. Med. 38, 192 (2017).

15. Lipscombe J., Lewis G.F., Cattran D., Bargman J.M.: Clin. Nephrol. 55, 39 (2001).

16. Nakajima T., Tanaka N., Kanbe H., Hara A., Kamijo Y., et al.: Mol. Pharmacol. 75, 782 (2009). 
17. Blair P.V., Kobayashi R., Edwards H.M., Shay N.F., Baker D.H., et al.: J. Nutr. 129, 641 (1999).

18. Wiltafsky M.K., Pfaffl M.W., Roth F.X.: Br. J. Nutr. 103, 964 (2010).

19. Strumilo S.: Biochem. Mol. Biol. Educ. 33, 284 (2005).

20. Smith C.M., Bryla J., Williamson J.R.: J. Biol. Chem. 249, 1497 (1974)

21. Lawlis V.B., Roche T.E.: Biochemistry 20, 2512 (1981).

22. McCormack J.G., Denton R.M.: Biochem. J. 180, 533 (1979).

23. Jiao H., Zhao B.: Toxicol. Appl. Pharmacol. 185, 172 (2002).

24. Ball M.R., Gumaa K.A., McLean P.: Biochem. Biophys. Res. Commun. 87, 489 (1979).

25. Knapik-Czajka M., Gozdzialska A., Jaskiewicz J.: Toxicology 266, 1 (2009).

26. Jang S., Yu L.R., Abdelmegeed M.A., Gao Y., Banerjee A., et al.: Redox. Biol. 6, 552 (2015).

27. Dai M., Yang J., Xie M., Lin J., Luo M., et al.: Br. J. Pharmacol. 174, 3000 (2017).

28. Nulton-Persson A.C., Szweda L.I.: J. Biol. Chem. 276, 23357 (2001).

29. Tretter L., Adam-Vizi V.: Trans. R. Soc. Lond. B. Biol. Sci. 360, 2335 (2005).
30. Hou X., Shen Y.H., Li C., Wang F., Zhang C., et al.: Biochem. Biophys. Res. Commun. 394, 653 (2010).

31. Inoue I., Goto S.I., Matsunaga T., Nakajima T., Awata T., et al.: Metabolism 50, 3 (2001).

32. Nakajima T., Tanaka N., Li G., Hu R., Kamijo Y., et al.: Redox Rep. 15, 123 (2010).

33. Schoolwerth A.C., LaNoue K.F.: Am. J. Physiol. 244, F399 (1983).

34. Winiarska K., Bozko P., Lietz T., Bryla J.: Acta Biochim. Pol. 45, 825 (1998).

35. Tokonami N., Morla L., Centeno G., Mordasini D., Ramakrishnan S.K., et al.: J. Clin. Invest. 123, 3166 (2013).

36. Cantó C., Menzies K.J., Auwerx J.: Cell Metab. 22, 31 (2015).

37. Nikiforov A., Kulikova V., Ziegler M.: Crit. Rev. Biochem. Mol. Biol. 50, 284 (2015).

38. Braidy N., Guillemin G.J., Mansour H., ChanLing T., Poljak A., et al.: PLoS One 6, 1 (2011)

39. Hershberger K.A., Martin A.S., Hirschey M.D.: Nat. Rev. Nephrol. 13, 213 (2017).

40. Broeders N., Knoop C., Antoine M., Tielemans C., Abramowicz D.: Nephrol. Dial. Transplant. 15, 1993 (2000).

41. Salgueiro G., Beltrán L.M., Torres R.J., Puig J.G.: Nucleos. Nucleot. Nucl. Acids 33, 181 (2014).

42. Ncube V., Starkey B., Wang T.: Ann. Clin. Biochem. 49, 491 (2012).

(C) 2020 by Polish Pharmaceutical Society. This is an open-access article under the CC BY NC license (c) (i) (\$) (http://creativecommons.org/licenses/by-nc/4.0/). 